[Article copies available for a fee from The Transformative Studies Institute. E-mail address: journal@transformativestudies.org Website: http://www.transformativestudies.org (C2010 by The Transformative Studies Institute. All rights reserved.]

\title{
Introduction:
}

\section{A Democracy of Hope: The Stubborn Legacy of Struggle}

\author{
Corey Dolgon ${ }^{1}$
}

From the Dust

From the mud

From the fields

The voices will rise

The voices of challenge.

Do not rest easy, do not be deceived

Those who have suffered and died

Those who have sacrificed for freedom

Their voices will challenge you

Endlessly, until we are free.

--Dennis Brutus, The Voices of Challenge

I am not one for scorecards when it comes to politics. In fact, the focus on short-term point scoring invites the kind of trite semantic skirmishes that flood the shrill and fickle 24/7 media menu. Such obsessive navalgazing obscures meaningful discussions about the real triumphs and failures we experience as global citizens trying to make the world a better place. If you watch or listen or upload, stream, download, or simply read the media's hyperbolic squabbles over birth certificates, death panels, terrorist sympathizers in the Justice Department or naked chiefs of staff accosting coquettish congressmen in the Capitol locker room, you might just fall victim to thinking that significant battles are being won or lost, moment to moment, in the halls of power and in the public's conscious-

\footnotetext{
${ }^{1}$ Corey Dolgon, Ph.D., is Professor of Sociology at Worcester State College and Assistant Editor of Theory in Action.
} 


\section{Corey Dolgon}

ness. However, as McLuhan once suggested about the media being the message, it may be that the major victor remains corporate power in its ability to maintain a population addicted to intellectual and political pabulum. Regardless, spending too much time engaged with these rhetorical spin-room brawls inevitably induces a paralyzing dose of cynicism.

But some people cut through, or better yet, transcend the media muck with both crystal clear, big picture analyses and powerfully effective but inherently humane prescriptions for addressing what ails us. Even more rare are strong public intellectuals who also commit themselves to activism; they not only write and speak out, but find themselves constantly on the front lines, the picket lines, the protest lines where people's hearts and minds meet the physical and emotional challenges of coming together to fight for change. Two such "lions of the left" recently passed away and I think it immensely appropriate for us to honor them in this issue of Theory and Action.

Howard Zinn and Dennis Brutus were scholar activists to the enth degree. They dedicated their lives-professionally and personally-to changing the world writ large and small. They were international personalities (in some circles even celebrities) who were never too big to help out local causes. Zinn might be performing his recent work, The People Speak, with Matt Damon and Danny Glover in Hollywood one day and be back on the streets of Boston picketing with janitors the next. Brutus could jet half way around the world to speak at a meeting of Jubilee 2000 (a campaign to end third world debt) and return a day later to convince a small group of students and faculty in Worcester, Massachusetts that they should start their own local social forum to organize and educate, "where you are with the people around you who are struggling for justice. The fight for liberation locally links you inevitably, undeniably with the fight for liberation globally." Their words spoke and inspired volumes, but their bodies, their presence, their passionate commitment and their humility, their sincere and genuine concern for those they met and taught and worked with leave a powerful legacy.

"Democracy does not come from the top; it comes from the bottom...the mutinous soldiers, the angry women, the rebellious Native Americans, the working people, the agitators, the anti-war protestors, the socialists and anarchists and dissenters of all kinds, the troublemakers, yes, the people who have given this country whatever liberty and democracy we have."

--Howard Zinn, The People Speak! 
Zinn's biography begins as a son of working class parents who eventually benefits from the G.I. bill to complete a graduate education at Columbia University. From his first professorial gig at the all-Black, all women's, Spellman College, through his many years at Boston University (where I first met him as a student in the early 1980s) Zinn's own intellectual and political trajectory was always evolving. In his autobiography, You Can't Be Neutral on a Moving Train, he wrote, "The events of my life, growing up poor, working in a shipyard, being in a war, had nurtured an indignation against the bullies of the world, those who used wealth or military might, or social status to keep others down." His radical world view was informed by the great historical and theoretical works of Thomas Jefferson, Frederick Douglas, Karl Marx, Peter Kropotkin, and W,E.B. Dubois, but these ideas were always received through and shaped by a constant ethical filter-a bedrock set of basic moral principles about how people should treat one another to insure each person's basic human rights and dignity. I remember sitting in his seminar (a 40 person seminar as a recall) on Anarchism and Marxism, thinking that Howard was not so much "teaching us" but trying to work out "with us" what it might mean to infuse a Marxist analytical framework of historical materialism and class struggle with the anarchist sensibilities about anti-authoritarian collective behavior, human creativity, compassion and love.

My most vivid memory of Howard in the classroom was the day he told a lecture hall of over 300 students - his average class size-that there was no logistical reason to explain why we didn't have free food in the United States. Every week he had some rhetorical bomb to drop that peeled away the thick veneer of ugly ideologies. And every week there was a core of conservative students who came to Zinn's classes to challenge him. A couple of students raised their hands and started a brief debate. But Howard incisively and humorously brushed off each naysayer who proposed that people would simply take advantage of such a system of free food. Howard's response: "Do you really think there would be a rush to obesity?"

I once asked Howard if such debates with privileged and conservative students got tiresome. He replied, "Any student who takes the time and effort to engage in a debate in class has to reconsider his or her argument, even if it's only to recast their own perspective in the most effective way. When they reconsider, they might also change their mind." As he says towards the end of his autobiography, "As dogma disintegrates, hope appears. Because it seems that human beings, whatever their backgrounds, are more open than we think, that their behavior cannot be con- 


\section{Corey Dolgon}

fidently predicted from their past, that we are all creatures vulnerable to new thoughts, new attitudes. And while such vulnerability creates all sorts of possibilities, both good and bad, its very existence is exciting. It means that no human being should be written off, no change in thinking deemed impossible."'In calm rational tones Howard radicalized common sense or, perhaps more appropriately, made radical ideas seem like common sense. When asked in class one day about being a "radical," Zinn said, "it doesn't take much in today's world to be a radical. All you have to do is look around at all of the contradictions and atrocities - war, hunger, and oppression - and suggest we do something about them and you seem radical."

\section{There will come a time}

There will come a time we believe

When the shape of the planet

and the divisions of the land

Will be less important;

We will be caught in a glow of friendship

a red star of hope

will illuminate our lives

A star of hope

A star of joy

A star of freedom

--Poem from Caracas, Venezuela, Dennis Brutus

Dennis Brutus was born in Rhodesia, now Zimbabwe, and grew up in South Africa. He graduated from Universities of Fort Hare and Witwatersrand, and soon after became involved in the Anti-Apartheid movement — himself classified as "coloured" being of mixed racial and ethnic ancestry. Arrested for political activities in 1960, Brutus jumped bail and fled to Mozambique. But he was quickly captured by Portuguese secret police and returned to South Africa. In an attempt to escape, Brutus was shot in the back and almost died as white ambulances refused to take him to hospital. He recovered, but soon after was convicted and sent to Robben Island where he broke rock and stone with Nelson Mandella and other heroes of the movement. From Robben Island he wrote poetry and smuggled it out as letters to his sister. After a 16 month prison term, he was released and exiled. While he taught for many years at colleges and universities in the United States, most of the last 25 years of his life was spent traveling the world fighting global inequality and oppression. 
I first saw Dennis as a college student in Boston when I attended a Pete Seeger concert at Northeastern where funds were being raised for Dennis's legal fees while fighting deportation. Years later I attended a Radical Scholars Conference in Chicago where he gave a talk about the rising global economy and the dilemmas facing a new South Africa. He laid out the battle as one between TINA [there is no alternative] and TMBA [there must be an alternative]. It was the first time I had ever heard someone use the phrase "Another world is possible," and suggest that one of the great oppressive forces in the world emanates from an unwillingness and inability to envision a better way to live." Later that day I ran into him on the snowy streets of the city and introduced myself, remembering the Boston concert. I asked him to sign a collection of his poems I had just purchased, and, as he did so, he asked what I was doing. I was finishing up a doctorate in American Culture at the University of Michigan and feeling somewhat torn about the politics of academic work and the institution itself. He encouraged me to finish and realize the great opportunities involved in teaching and writing. And he made sure to include that neither precluded radical organizing nor activism - one needed to act and organize wherever they were.

Ten years later, Dennis became a Poet-in-Residence at Worcester State College in Massachusetts where I was Chair of Sociology. Worcester State had hired him at a crucial time in his anti-deportation battle and his loyalty brought him back to the small, working -class institution time and time again. We had many opportunities to break bread together, organize events, and, since he never drove, I also got to be one of his legions of unofficial chauffeurs. Once, on a trip from Worcester to Cambridge, where Dennis was to give a talk for an international economic development course at the Kennedy School of Government, I asked if he was prepared to enter the lion's den where the cubs of greedy commerce cut their teeth. He laughed and said, "I speak whenever and wherever people ask me to and I can make it. You can never predict the impact you may have on others - especially those who either think differently than you or who are too shy or afraid to voice their opposition to violence and oppression. So you enter everybody's classroom, and living room, and kitchen, and especially their dens."

Later, he spoke eloquently to a class of 70 graduate students about the need for debt relief and organized grass roots actions around the world to achieve more democratic economic institutions. While many students clearly supported or at least respected his proclamations, one student with a strident streak of condescension asked if "so-called grass roots" social movements ever really changed anything, and if they had, were 


\section{Corey Dolgon}

they still relevant in the face of global changes that promised the democracy of market economics and economic growth. I remember thinking that I could not have handled such impudence as calmly as Dennis-he simply said, "Yes, such movements are the only way to bring about the kind of democratic institutions and equality we seek. Without them, your own country would not exist. As a coloured man I would not be welcome in many institutions such as this. And I would not be able to travel back to my home country and have dinner with the current leaders of South Africa who were once my prison mates."

Both Howard Zinn and Dennis Brutus will be missed. Their voices and their work will remain unique and cherished. But we have also lost two important figures "on the line." Both men had the ability to speak to gatherings great and small about the need for action and the possibility of liberation. Dennis never promised victory, but always acted as if it was possible regardless of doubt - as Martin Espada suggests in his poem for Dennis, Stone Hammered to Gravel, "Did you know slamming the hammering into the rock's stoic face/that a police state is nothing but a boulder/waiting for the alchemy of dust?" His confidence came from hope, and for both men, hope came as the gift of history - the gift of past struggles. "Pessimism becomes a self-fulfilling prophecy;" Zinn concluded in his memoirs, "it reproduces itself by crippling our willingness to act." He continued:

We forget how often in this century we have been astonished by the sudden crumbling of institutions, by extraordinary changes in peoples thoughts, by unexpected eruptions of rebellion against tyrannies, by the quick collapse of systems of power that seemed invincible....Political power, however formidable, is more fragile that we think. Ordinary people can be intimidated for a time, can be fooled for a time, but they have a deep-down common sense, and sooner or later they find a way to challenge power that oppresses them.

Revolutionary change does not come as one cataclysmic moment (beware of such moments!) but as an endless succession of surprises, moving zigzag towards a more decent society. We don't have to engage in grand, heroic action to participate in the process of change. Small acts, when multiplied by millions, of people, can transform the world. 
And as each man acted "as if" the world could be changed, they joined others in protest on picket lines, at meetings and demonstrations, in theaters and prisons and court rooms and classrooms and living rooms. And as we came together in struggle, we could envision what a new world might be like, look like, might feel like and it became real. We thank them for that vision, that experience, that gift, and we commit ourselves, in their memory, to live "now as we think all human beings should live, in defiance of all that is bad around us, [which] is itself a marvelous victory."

As always, Theory and Action brings us the kinds of articles that encourage and nurture us as we try to create such a world. In "Selectively Forgetting Baudrillard: Rescuing Praxis from the Wreckage," Richard Gilman-Opalsky takes the French philosopher to task for attacking the "viability of viability of political projects and normative philosophy." Reminding us that philosophers must be measured by their efforts to change the world, not just interpret it," Gilman-Opalsky applauds Baudrillard's ability to understand late capitalism and its attendant culture, but wonders what is left when such critique leads only to a fatalistic and condescending attitude towards social movements and collective action for change.

Next, in "Post Civil Rights Racism and the Need to Challenge Racial/Ethnic Inequality Beyond the Limits of Liberalism," Luigi Esposito and John W. Murphy argue that racism is inherent to liberalism itself and we must go beyond such philosophies and ideologies to find an antiracist future. More notably, they "suggest that achieving racial/ethnic equity in the United States demands anti-racist projects guided by alternative social imagery that breaks from the typical trappings associated with liberalism/neo-liberalism." We create a new world of possibilities in struggle.

Victories, even minor and partial ones, are not easily won and they are rarely met without increased pressure from reactionary and conservative forces. Such can be seen in Denise Dentice and James Williams' article, "The First 100 Days Stormfront Responds to Obama's Presidency." Here we see the magnitude and vitriol of the white supremacist reaction to Barak Obama's presidency. The authors give us an effective analysis of this movement and its potential to wipe out the historical impact of wellfought battles. While white supremacy may never be the dominant ideology of our time, its intensity and growing momentum also informs the more conservative and oppressive forms of liberalism that may all to likely return to power. 


\section{Corey Dolgon}

Finally, we have John Leveille's article, "Tropic Constructions of Self." Leveille contends that there are three particular tropic strategies-reductionist, structuralist, and humanist/anti-humanist whereby the human sciences consider the development of ideas of "the self". Thinking about how we as intellectuals develop some of the most important concepts such as self and society, help us consider how various theoretical constructs impact not only our analyses, but also the actions related to such theories. Such inquiries comprise the lifeblood of our enterprise. Amandla! 
Theory In Action is published quarterly by the Transformative Studies Institute. Subscription rates (\$USD) for the print version are:

Individuals: $\$ 35.00$ per single issue, $\$ 105.00$ yearly with free online access*.

Institutions: $\$ 200.00$ per year print with free online access*.

*For orders within the continental U.S. add \$2.00 for shipping \& handling per individual issue, $\$ 8.00$ for yearly subscription. For orders outside the continental U.S. I add $\$ 25.00$ for shipping \& handling per individual issue, $\$ 100.00$ for yearly subscription.

Individual and institutional subscription orders can be placed online at:

http://transformativestudies.org/content/theory-in-action-the-journal-of-

tsi/subscriptions/

Alternatively, you may mail this form to:

Transformative Studies Institute, Orders, 39-09 Berdan Avenue, Fair Lawn, NJ 07410

First Name: MI Last Name:

Mailing Address:

Institution:

Street:

Apt. \#

City:

State/Provence:

Country: Postal Code:

Tel.: Email:

One Year Subscription:

$\square$ Individual

$\square$ Institutional

or

Single Issue: Vol.

No. Year Number of Copies:

Order Total: \$US (Do not forget to add Shipping \& Handling*)

$\square$ I am enclosing a check or money order made payable to: Transformative Studies Institute

$\square$ Please charge my credit card: $\square$ Visa $\square$ Mastercard $\square$ American Express $\square$ Discover Card number

Expiration date

CVC Code (last 3 digits on the back of the card)

Signature Date (MM/DD/YYYY)

Transformative Studies Institute is a U.S. registered 501(c)(3) tax-exempt nonprofit organization. All funds received by TSI are tax-deductible. 
Dear reader: If you wish to recommend this journal to your library fill out the information below and forward it to your institution's librarian in charge of serials/orders or electronic resources specialist.

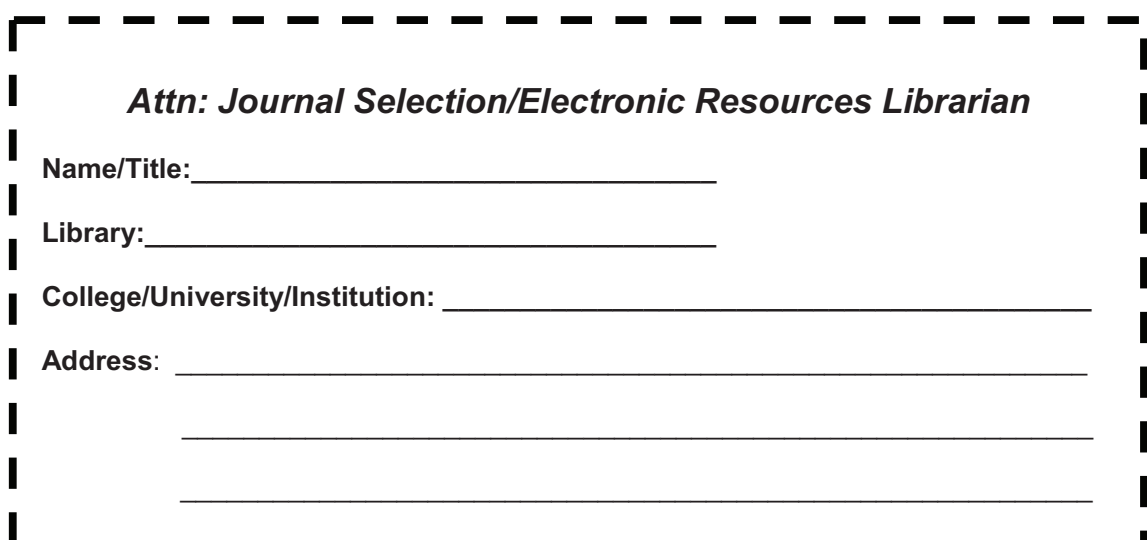

I Here is our library recommendation for the print journal:

Theory in Action (Print ISSN 1937-0229)

Recommended by:

Name:

Title:

Department:

Signature: Date (MM/DD/YYYY):

I plan to use this journal:

I as a publication outlet for articles as class handouts

$\square$ professional discussions

$\square$ for my own research

$\square$ for coursework assignments

$\square$ other

Name:

Title:

Department:

Signature:

Date (MM/DD/YYYY):

I plan to use this journal:

$\checkmark$ as a publication outlet

$\square$ for articles as class handouts

$\checkmark$ professional discussions

for my own research

$\square$ for coursework assignments

$\square$ other 


\title{
Transiormative Studies Institute
}

\author{
"PUTTING THEORY INTO ACTION!"
}

\section{About}

The Transformative Studies Institute (TSI) fosters interdisciplinary research that will bridge multidisciplinary theory with activism in order to encourage community involvement that will attempt to alleviate social problems. As part of the mission, scholars, activists, and other concerned individuals in fields such as social sciences, humanities, and law will be invited to conduct research and become involved in like-minded various grass roots organizations. The Institute is concerned with issues of social justice and related activism, and its aim is to provide a working model of theory in action, through shared research, governance, and operation of the center. As such, the institute may provide a working laboratory for evolutionary socioeconomic forms of organization. Further, we invite literary participation through our independent, peer-reviewed journal Theory in Action, through which research associates, scholars, activists, and students may disseminate their research and expand thematic social dialogue. TSI also welcomes opportunities to work with national and international scholars who serve as research associates and fellows. In addition, the institute plans on collaborating with various worker education programs, labor centers, universities, think tanks, advocacy groups and non-profit organizations. TSI is managed and operated by a dedicated global team of academic scholar-activists, grassroots activists, and the concerned public. Many of TSI's members have multiple graduate degrees, multiple years of secondary and college level teaching experience throughout most disciplines. TSI also provides consulting services, custom policy papers and projects, and operates a speakers' bureau.

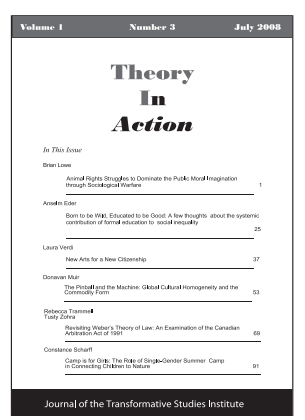

\section{Publish with our Journal}

Ever wonder why activist scholarship is routinely rejected by 'serious' peer-reviewed journals? So did we and decided to do something about it! The purpose of our flagship journal Theory in Action is to legitimize scholar-activism through an international, interdisciplinary, peer-reviewed, quarterly publication that is available both in print and online. If you are too radical for acceptance by your association's journals, well check us out because WE WANT YOU! We welcome assistance in disseminating our journal through your social networks and increasing its subscription base through your recommendations to your institution's librarian.

\section{Fellowships}

If you wish to pursue grants without institutional restraints, you may now do so as a TSI research Fellow or Associate. We recognize that journals, colleges, and foundations often do not take contingent faculty and independent scholars seriously. TSI, however, believes that all scholars have something to contribute, which is why we offer them an opportunity to affiliate with TSI as research Fellows and Associates. Upon acceptance, scholars will be able to affiliate with TSI as their home institution. We will provide support, institutional email, letterhead, and other materials. Furthermore, since we do not require exclusive rights to their intellectual work, our scholars are free to disseminate their research through any outlet.
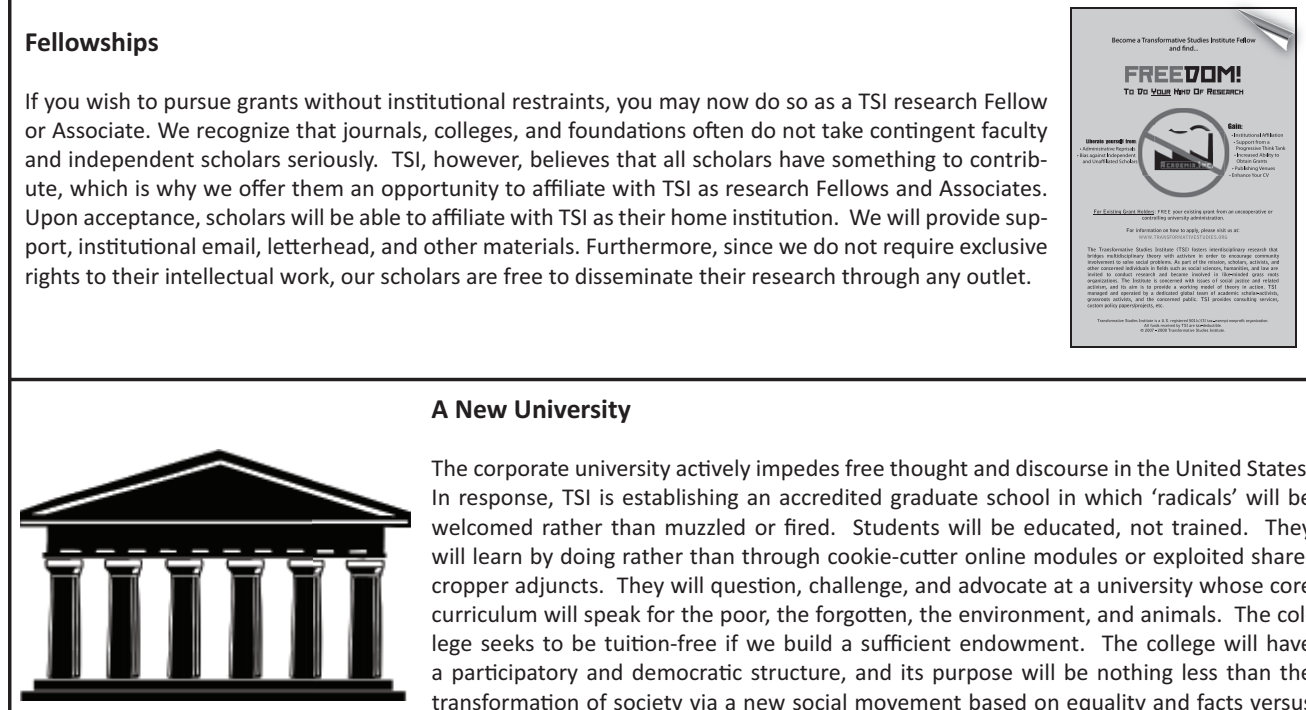

\section{A New University}

The corporate university actively impedes free thought and discourse in the United States. In response, TSI is establishing an accredited graduate school in which 'radicals' will be welcomed rather than muzzled or fired. Students will be educated, not trained. They will learn by doing rather than through cookie-cutter online modules or exploited sharecropper adjuncts. They will question, challenge, and advocate at a university whose core curriculum will speak for the poor, the forgotten, the environment, and animals. The college seeks to be tuition-free if we build a sufficient endowment. The college will have a participatory and democratic structure, and its purpose will be nothing less than the transformation of society via a new social movement based on equality and facts versus poverty, propaganda, and superstition!

\section{WWW.TRANSFORMATIVESTUDIES.ORG}

Transformative Studies Institute is a U.S. registered 501(c)(3) tax-exempt nonprofit organization.

All funds received by TSI are tax-deductible.

(C) 2007-2010 Transformative Studies Institute. 


\section{Become a Transformative Studies Institute Fellow and find...}

\section{FREEDTM! \\ Tu Do YruR HiNg Df ReseaRch}

Liherate yourself from:

- Administrative Reprisals

- Bias against Independent and Unaffiliated Scholars

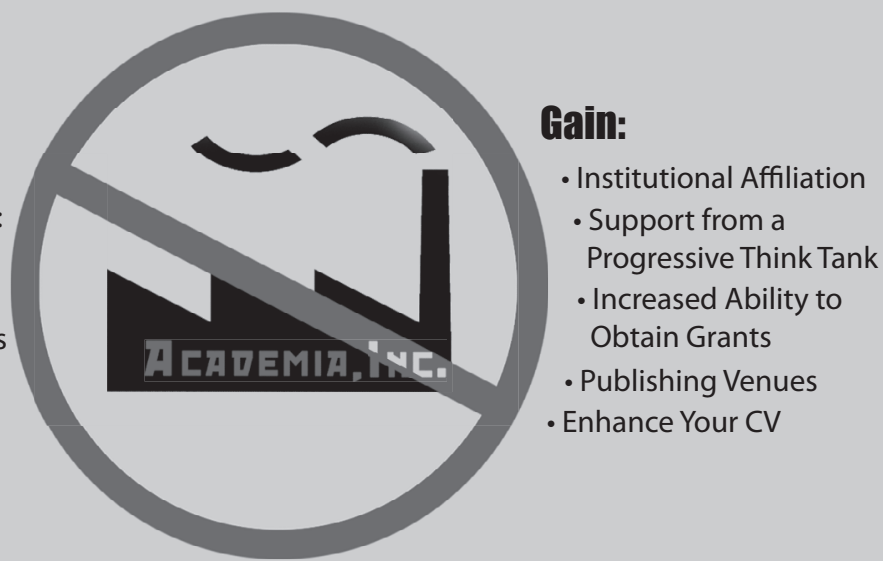

For Existing Grant Holders: FREE your existing grant from an uncooperative or controlling university administration.

For information on how to apply, please visit us at:

WWW.TRANSFORMATIVESTUDIES.ORG

The Transformative Studies Institute (TSI) fosters interdisciplinary research that bridges multidisciplinary theory with activism in order to encourage community involvement to solve social problems. As part of the mission, scholars, activists, and other concerned individuals in fields such as social sciences, humanities, and law are invited to conduct research and become involved in like-minded grass roots organizations. The Institute is concerned with issues of social justice and related activism, and its aim is to provide a working model of theory in action. TSI is managed and operated by a dedicated global team of academic scholar-activists, grassroots activists, and the concerned public. TSI provides consulting services, custom policy papers/projects, etc. 


\section{In Search of One Big Union: \\ A Singing Lecture by Corey Dolgon, Folksinger \& Sociologist}

Corey Dolgon, a Ph.D in American Culture and Sociology Professor has been performing "singing lectures" for almost a decade. Focusing on the role that folksongs play in the U.S. labor movement, Corey's words and music bring both history and theory to life. He is a long-time labor activist and community organizer and has used folk songs to build solidarity on the line and engage students in the classroom. This singing lecture covers labor history from a multicultural perspective and examines the function of folk songs in workers' lives, labor, and organizing.

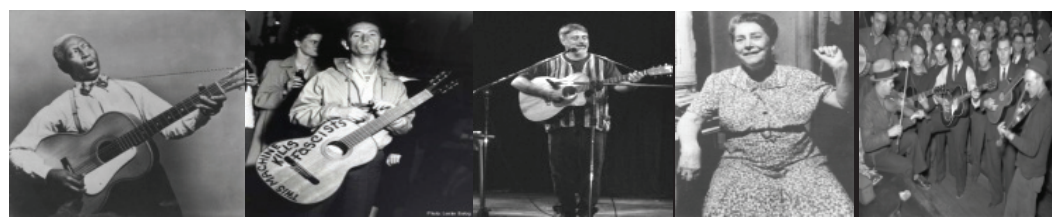

"I learned about the importance and power of strikes and labor unions. I never knew there were songs about them. [The lecture] made the period come alive for me."

--Stonehill College student

"Corey's work weaves together a coherent and accessible narrative about labor struggles with a tour de force of labor songs that moves audiences."

--Chris Dale, Professor of Sociology, New England College

“Corey's music added tremendous spirit to our National Labor Assembly. I encourage other unions to add Corey's talents and expertise to their agendas."

--Cheryl Johnson, President, United American Nurses, AFL-CIO

“Corey Dolgon's "singing lecture" is a hit. From union retirees to active union members, from academics to management, all received a good time and good learning."

--John Ralston, U. of Louisville Labor-Management Center

"Corey's wonderful voice, abundant energy, and great knowledge about folksongs, labor, and other social movements were entertaining, very informative, and inspiring."

--Kathleen Odell Korgen, Professor of Sociology, William Patterson U.

Please contact Corey for scheduling a lecture or receiving a sample CD at 617-298-0388 or at cdolgon@worcester.edu.

More info@www.coreydolgon.com 